\title{
FEED ADDITIVE VINIVET OF APICULTURAL PRODUCTS AS AN ALTERNATIVE FOR ANTIBIOTIC GROWTH PROMOTERS IN BROILER CHICK DIETS - BACTERICIDAL AND BIOSTIMULATING EFFECT
}

\author{
E.N. ANDRIANOVA ${ }^{1}$, I.A. EGOROV ${ }^{1}$, L.M. PRISYAZHNAYA ${ }^{1}$, \\ L.T. AKHMETOVA ${ }^{2}$, Zh.Zh. SIBGATULLIN ${ }^{2}$, N.A. SLESARENKO ${ }^{3}$, \\ G.V. KONDRATOV ${ }^{3}$, I.N. NIKONOV ${ }^{4}$, G.Yu. LAPTEV 4
}

\begin{abstract}
${ }^{1}$ All-Russian Research and Technological Poultry Institute, Federal Agency of Scientific Organizations, 10, ul. Ptitsegradskaya, Sergiev Posad, Moscow Province, 141311 Russia, e-mail andrianova@vnitip.ru;

${ }^{2} J S C$ «Rusoborotexport», 49a, prosp. Yamasheva, Kazan, 420124 Russia, e-mail info@rusoborotexport.ru;

${ }^{3}$ K.I. Skryabin Moscow State Academy of Veterinary Medicine and Biotechnology, 23, ul. K.I. Skryabina, Moscow, 109473 Russia, e-mail kazagor@gmail.com;

${ }^{4}$ JSC «Biotrof», Kolpino, St. Petersburg, 192288 Russia, e-mail ilnikonov@yandex.ru

Received December 18, 2015
\end{abstract}

\section{Abstract}

Preservation of national gene pool requires the maintenance of quality standards of life including healthy nutrition. In this relation there is a particular public concern about the use of antibiotic growth promoters (AGPs) as an essential part of intensive technologies of animal production, the remnant of the past when it was a commonplace. WHO reported the constant growth of microbial resistance partly due to the transfer of AGPs into animal food products; it could enhance the distribution of bacteria resistant to antibacterial drugs and drug-resistant diseases hazardous for human race. The distribution of these infections among animals (especially breeding flocks) is also hazardous. This hazard is probably underestimated as a result of the lack of knowledge on composition and possible changes in animal and human microbiome including microorganisms undetectable by classic microbiological methods but forming the basis of the microbiota. Another underestimated possibility is the transfer of beneficial biologically active substances to human via animal food products when undesirable ingredients of animal feeds are simply substituted by harmless and biologically active ones, while more costly approaches to production of functional animal foodstuffs are widely discussed. Problem solving must be rapid, economically and biologically effective and safest for human, animals, and environment. In our trials conducted on 3 groups of Cobb-500 broiler chicks (from 1 to 35 days of age) the possibility of substitution of feed additive Vinivet for AGPs in diets for broiler chicks was studied. This additive based on apicultural products, i.e. bee-bread (ambrosia) and slumgum, was produced by no-waste technology (JSC Rusoborotexport, Kazan, Russia) preserving biologically active compounds from these products. It was found that inclusion of Vinivet into broiler diets $(5000 \mathrm{ppm})$ improved live bodyweight in group 3 compared to control group 1 (no Vinivet) by 0.61 and $0.86 \%$ at 28 and 35 days of age, respectively; feed conversion rate (FCR) in group 3 was better by $3.15 \%$ compared to control. AGP Stafac 110 (Phibro Animal Health Corp., USA) fed to group $2(180 \mathrm{ppm})$ was found to improve growth rate of broilers compared to groups 1 and 3. Live bodyweight in group 2 was higher than in control at $6,14,21,28$ and 35 days of age by $2.63 ; 1.99 ; 3.22 ; 0.51$ and $2.04 \%$, respectively, while FCR in group 2 was better by $3.53 \%$. The analysis of intestinal microbiota with the use of T-RFLP (Terminal Restriction Fragment Length Polymorphism) method showed substantial decline in pathogenic and opportunistic populations in broilers of Vinivet-fed group 3. The counts of Staphylococcaceae, Fusobacterium spp., Pertococcaceae and Pasteurellaceae were significantly lower compared to control (by $0.91 ; 0.79 ; 1.85$ and $3.37 \%$, respectively) while total count of cellulolytic bacteria was higher by $7.94 \%$. Histological study of liver and intestine showed structural changes in small intestine of Vinivet-fed broilers improving its absorbing ability, barrier and motor functions. The height of intestinal villi in group 3 was significantly higher compared to control, density and depth of crypts were higher as well as the total absorbing surface area. To the contrary, in Stafac-fed group 2 the decrease in thickness of mucosa of intestinal wall was found which could mean the decrease in intestinal functionality. The activation of trophic processes in liver was also found in Vinivet-fed broilers. The histological analysis of liver showed the absence of hepatotoxic effect of Vinivet for broilers. The results of our trial proved Vinivet to be a promising 
Keywords: broiler chicks, antibiotic growth promoters, productivity, apicultural products

Increasing production, improving quality and reducing the cost of eggs and meat are the most important objectives of poultry. Currently, much attention is paid to provide people with functional food, as nutrition is one of the most important factors in healthy lifestyle and gene pool maintaining. Proper nutrition helps to prevent diseases and prolong life, increases the ability to resist the adverse agents, and provides normal growth and development of children. The dietary properties of poultry products in combination with their enrichment with biologically active components allow controlling essential nutrient levels in consistence with medical and biological requirements. The demand for highquality and environmentally friendly products is increasing [1-3].

An approach in the functional nutrition concept supposes to limit the use of feed antibiotics in poultry to produce safe meat and eggs without residual amounts of antibiotics [4, 5]. The World Health Organization (WHO) notes the growing microbial resistance (including that due to the transition of antibiotics in animal production and human consumption, consequently), which may result in the spread of bacteria resistant to antibacterial agents and drug-resistant infections that pose a threat to humanity [6-8]. A not less risk lies in the spread of such infections in livestock, in breeding stock especially.

Possibly, the threat is underestimated greatly, since the composition and changes in microbiome have not been actually studied in animals and humans. Thus, it is generally believed that the gastrointestinal tract (GIT) of avian embryos is sterile [9-12], and the formation of digestive system microbiocenosis occurs after hatching as a result of contacts with the environment [13-15]. However, there is evidence obtained by the methods of classical microbiology [16] and using real-time PCR [17] which indicates the ability of microorganisms to colonize the digestive tract of poultry embryos.

Renewable low-demand apicultural products containing an extensive range of vitamins, amino acids, macro-, and micronutrients are a promising source of raw materials for feed additives with a diversified action [18-20], so that they can be natural physiological and biochemical stimulators in poultry, contributing to the improvement of palatability and ecological purity of the final product. It is noteworthy that the bactericidal properties of honey, pollen, propolis have been investigated extensively [21], while the similar effect of slumgum, a byproduct, not been studied actually.

We first demonstrated the possibility of substituting antibiotic growth promoter (AGP) Stafac 110 (Phibro Animal Health Corp., USA) widely used in Russian industrial poultry by the feed additive Vinivet (Rusoborotexport LLC, Kazan, Russia) based on apicultural product. This additive was found not to be inferior to the antibiotic for the parameters studied (microflora composition of intestinal blind processes in chickens, gastrointestinal tract and liver micromorphology) while also helping to increase poultry growth rate.

Our purpose was to compare biostimulatory and bactericidal effects of Vinivet feed additive and AGP.

Technique. Three groups of Cobb-500 broiler chickens from 1 to 35 days of age (FSUE Zagorskoe EPH VNITIP vivarium, Moscow Province) were fed ad libitum with dry complete feed according to recommended standards (AllRussian Scientific Research and Technology Poultry Institute - VNITIP, 2014) [22]. In control group 1 a balanced complete feed (basic diet - BD) was used. Group 2 poultry within the observation period were fed similar diet supple- 
mented with AGP Stafac 110 (Phibro Animal Health Corp., USA) at a dose of $180 \mathrm{~g} / \mathrm{t}$ of complete feed as recommended by manufacturer, and in experimental group 3 the antibiotics were replaced by apiculture product based feed additive Vinivet (Rusoborotexport LLC, Kazan, Russia) at a dose of $5 \mathrm{~kg} / \mathrm{t}$ of complete feed. In the first 3 days, the broilers of all groups were given the same pre-start complete feed, further fed according to the experimental scheme. Veterinary measures were in accordance with the vaccination plan accepted at the farm. Broilers were kept in R15 cages (Germany), 35 broilers in each group with no gender separation. Housing conditions complied with VNITIP recommendations. Feed was given manually.

Main zootechnical parameters recorded were live bodyweight at the age of 7, 21, and 35 days (individual weighing), mortality rate, and average daily weight gain. Feed conversion rate per $1 \mathrm{~kg}$ of live weight gain were calculated, and the levels of vitamins and carotenoids in the liver, chemical composition of the liver, pectoral and femoral muscles were assayed by conventional methods [23].

35-Day-aged $(n=21)$ broilers were used for histological studies. Liver and disemboweled intestinal canal were sampled within $1 \mathrm{~h}$ after slaughter and fixed in $10 \%$ formalin for one day. After washing in running water, samples were dehydrated in alcohol (70-96\%). Paraffin-embedded tissue sections were prepared using a HM-325 universal automated microtome (Microm international GmbH, Germany). General morphology was studied using a light microscope (Nikon, Japan) after staining with hematoxylin and eosin. Photomicrography and microscopic morphometry with statistical processing were performed using certified ImageScope C microscope combined image analysis software (Systems for Microscopy and Analysis LLC, Russia).

Cecum microbiota was studied using T-RFLP (Terminal Restriction Fragment Length Polymorphism) analysis [24].

Statistical processing of zootechnical parameters and T-RFLP-analysis data was performed by standard methods [25].

Results. It is noteworthy that zootechnical parameters in the course of the experiment were high: in all the groups loss of broilers through natural death was not registered and the feed per unit of gain (feed efficiency) complied with general standards not exceeding $1.6 \mathrm{~kg}$ per $1 \mathrm{~kg}$. Average daily weight gain in control broilers was $60.21 \mathrm{~g}$ (Table 1).

The obtained data showed AGP Stafac 110 to provide higher growth rate. Thus, the live weight in group 2 broilers exceeded control at the ages of $6,14,21$ and 28 days by $2.63,1.99,3.22$, and $0.51 \%$, respectively, and by the end of growing period, the difference in average live weight in groups 2 and 1 was $2.04 \%$. In this, feed conversion rate was better compared to control (by $3.53 \%$ ).

Our data are consistent with the results of numerous studies [26] which prove that the use of antibiotic growth promoters, due to inhibition of gastrointestinal tract (GIT) pathogenic microflora, not only contributes to poultry survival rate, but also has a growth stimulating effect in chicken which is especially noticeable in their early stages.

Apicultural products are known to have a pronounced antibiotic effect on gastrointestinal pathogenic microflora [21]. However, their efficiency is still inferior to antibiotic growth promoters, as evidenced by the zootechnical parameters we obtained in the experiment. In fact, AGP Stafac 110 at a dose of $180 \mathrm{~g} / \mathrm{t}$ improved live weight in group 2 broilers compared both to the parameters of control and Vinivet-fed $(5 \mathrm{~kg} / \mathrm{t}$ of feed) groups.

Despite the lower efficiency of Vinivet additive, its application in a dose 
of $5 \mathrm{~kg} / \mathrm{t}$ still had a growth promoting effect on broilers. Group 3 chicken live weight was by 0.61 and $0.86 \%$ greater compared to control at the age of 28 and 35 days (differences in male chickens were significant at $\mathrm{p}<0.05$ ), and feed consumption per $1 \mathrm{~kg}$ gain was $3.15 \%$ lower, which confirms the usefulness of Vinivet in feeding meat poultry. In the early growing (at the age of 14 and 28 days), Vinivet use resulted in a slight growth retardation $(3.38$ and $0.58 \%$, respectively) in group 3 broilers compared to control.

1. Zootechnical parameters in Cobb-500 broiler chickens with the use of AGP Stafac 110 and apicultural product based feed additive Vinivet $(M \pm m$, FSUE Zagorskoe EPH VNITIP vivarium, Moscow region)

\begin{tabular}{|c|c|c|c|}
\hline \multirow{2}{*}{ Parameter } & \multicolumn{3}{|c|}{ Group } \\
\hline & 1 (control) & 2 (Stafac 110) & 3 (Vinivet) \\
\hline Stock preservation, $\%$ & 100 & 100 & 100 \\
\hline \multicolumn{4}{|l|}{ Live weight at various ages, g: } \\
\hline day 1 & 40.0 & 40.0 & 40.0 \\
\hline day 6 & $152.54 \pm 8.60$ & $156.54 \pm 1.83$ & $156.37 \pm 1.80$ \\
\hline day 14 & $435.37 \pm 7.85$ & $444.03 \pm 10.07$ & $420.64 \pm 8.75$ \\
\hline day 21 & $873.71 \pm 14.12$ & $901.82 \pm 20.86$ & $868.64 \pm 13.99$ \\
\hline day 28 & $1462.51 \pm 19.45$ & $1470.00 \pm 29.40$ & $1471.48 \pm 21.23$ \\
\hline \multicolumn{4}{|l|}{ Average live bodyweight, kg: } \\
\hline $\begin{array}{l}\text { at the age of } 35 \text { days } \\
\text { including }\end{array}$ & 2086.8 & 2129.42. or $+2.04 \%$ & 2104.81 \\
\hline male chickens & $2120.00 \pm 26.78$ & $2232.15 \pm 56.47$ & $2233.86 \pm 35.45^{*}$ \\
\hline female chickens & $2053.60 \pm 34.28$ & $2026.68 \pm 33.64$ & $1975.75 \pm 26.33$ \\
\hline Feed conversion rate per broiler, $\mathrm{kg}$ & 3.195 & 3.098 & 3.100 \\
\hline \multicolumn{4}{|l|}{ Feed conversion rate per $1 \mathrm{~kg}$ of live } \\
\hline Daily live weight gain, $\mathrm{g}$ & 60.21 & 61.45 & 60.73 \\
\hline \multicolumn{4}{|c|}{$\begin{array}{l}\text { N o t e. Basic diet was supplemented with Stafac } 110 \text { (Phibro Animal Health Corp., USA) and Vinivet (Rusoboro- } \\
\text { texport LLC, Kazan, Russia), } 180 \mathrm{~g} / \mathrm{t} \text { and } 5 \mathrm{~kg} / \mathrm{t} \text {, respectively. } \\
{ }^{*} \text { Differences are significant in group } 3 \text { male chickens at } \mathrm{p}<0.05 \text {. }\end{array}$} \\
\hline
\end{tabular}

2. Vitamin levels ( $\mu \mathrm{g} / \mathrm{g})$ in 35-day-old Cobb-500 broiler chicken liver with the use of AGP Stafac 110 and apicultural product based feed additive Vinivet (FSUE Zagorskoe EPH VNITIP vivarium, Moscow region)

\begin{tabular}{l|ccr}
\hline \multirow{2}{*}{ Parameter } & \multicolumn{3}{c}{ Group } \\
\cline { 2 - 4 } & 1 (control) & 2 (Stafac 110) & 3 (Vinivet) \\
\hline Vitamin A & 205.03 & 191.53 & 180.81 \\
Vitamin E & 9.20 & 5.73 & 10.03 \\
Vitamin B & 10.77 & 10.14 & 10.11 \\
Carotenoids & 4.69 & 3.03 & 4.77
\end{tabular}

N o t e. The basic diet was supplemented with Stafac 110 (Phibro Animal Health Corp., USA) and Vinivet (Rusoborotexport LLC, Kazan, Russia) at the doses of $180 \mathrm{~g} / \mathrm{t}$ and $5 \mathrm{~kg} / \mathrm{t}$, respectively. According to the method used, the differences are considered significant if the difference in the levels of vitamins $\mathrm{A}$ and $\mathrm{E}$ exceeds $20 \%$ and $15 \%$ for vitamin $\mathrm{B}_{2}$ and carotenoids, i.e. there was a significant decrease in vitamin $\mathrm{E}$ and carotenoids levels in group 2.

It was found (Table 2) that the use of additives with an antiseptic effect may result in decreased vitamin deposition in broiler liver. Thus, vitamin $\mathrm{E}$ and carotenoids levels in group 2 broilers treated with Stafac 110 antibiotic reduced significantly compared to control (by 37.70 and $35.40 \%$, respectively), while with the use of feed additive Vinivet, the differences in vitamin $\mathrm{A}$ and $\mathrm{B}_{2}$ deposition did not exceeded the method error (11.80 and $6.12 \%$, respectively), and accumulation of vitamin $\mathrm{E}$ and carotenoids increased slightly (by 9.02 and $1.71 \%$, respectively) which indicates a decrease in the negative impact of this natural antiseptic on GIT microbial community in group 3 broilers.

T-RFLP-analysis of intestinal microbiota demonstrated a substantial decrease of pathogenic and opportunistic microoranisms in broiler cecum in Vinivetfed group. The counts of Staphylococcaceae, Fusobacterium sp., Pertococcaceae, and Pasteurellaceae decreased significantly $(\mathrm{p} \leq 0.05)$ by $0.91 ; 0.79 ; 1.85$, and 
$3.37 \%$ compared to control, while total count of cellulolytic bacteria was higher by $7.94 \%$ (Table 3 ).

Light-optical histological study of intestinal wall showed the presence of common structural organization features in all the groups studied; the intestinal wall was differentiated into a number of layers: mucous (inner) layer which consists of epithelial cover, lamina propria, muscularis mucosa, and submucosal layer; muscle (intermediate) layer consists of two layers of smooth muscle cells (inner circular and outer longitudinal muscles); serous (outer) layer which includes mesothelial cells and a connective tissue formation (Fig. 1-3, A, B).

3. T-RFLP analysis of microorganism composition (\%) in cecum contents in 35day-old Cobb-500 broiler chickens with the use of AGP Stafac 110 and apicultural product based feed additive Vinivet $(X \pm X$, FSUE Zagorskoe EPH VNITIP vivarium, Moscow Province)

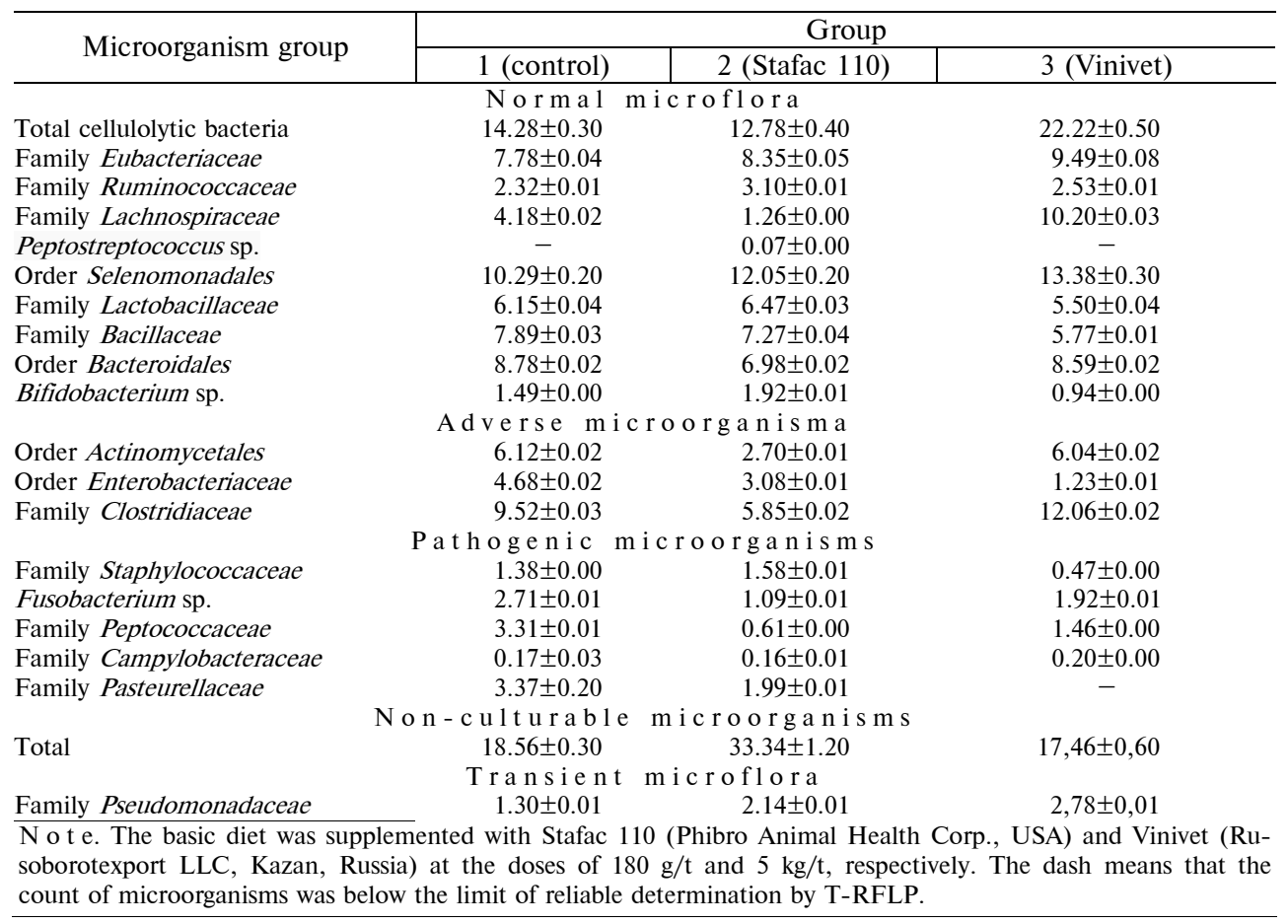

Micromorphologically, in the liver there were hepatocyte rows separated by blood capillaries with a clear differentiation of the central vein and hepatic triads (Fig. 1-3, B).

In group 3 chickens fed basic diet supplemented with natural apicultural based product, the structural changes improving the absorbing capacity, barrier and motor functions were identified in the small intestine. They included a significant ( $\mathrm{p} \leq 0.05$ ) increase in mucosal thickness, lengthened intestinal villi, greater crypt density and depth, increased total absorptive surface area (Fig. 3, A, Table 4). In Stafac 110-fed group 2, mucosal thickness was decreased which may indicate a decrease in intestinal functionality (Fig. 2, 3, A, B).

Micromorphological analysis of intestinal muscular membrane revealed its thickening in experimental groups versus control (in particular, by $40.3 \%$ in the small intestine and by $30.1 \%$ in large intestine in group 3) indicating its motor function enhancement in chickens fed basic diet supplemented with feed additive Vinivet.

No significant intergroup differences were found in the thickness of intestinal serous membrane. 
In group 3 chickens, liver parenchyma was penetrated with a larger number of blood capillaries closely associated with hepatic beams, a moderate blood supply was characteristic of it, no destructive changes were found in the liver (Fig. 3, C). Thus, activation of trophic processes in the liver caused by supplementing diet with Vinivet was not followed by toxic effects on the liver tissue as evidenced by its structure and suggests safety of the study product in poultry when used as a feed additive.

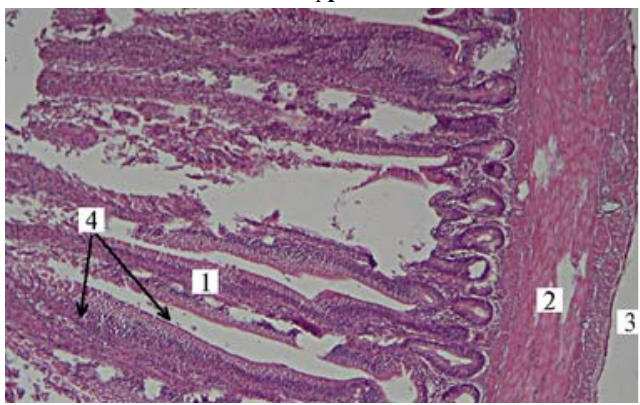

C

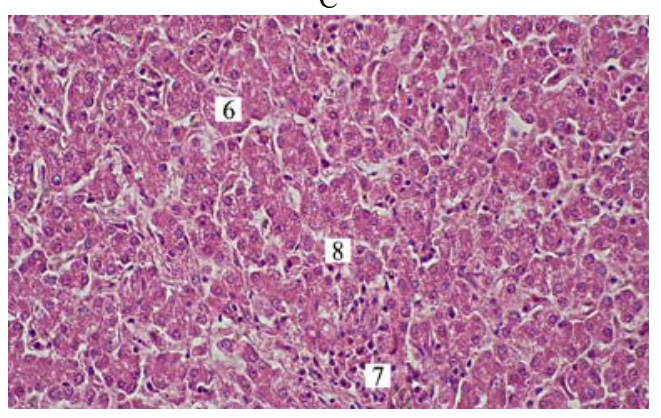

A

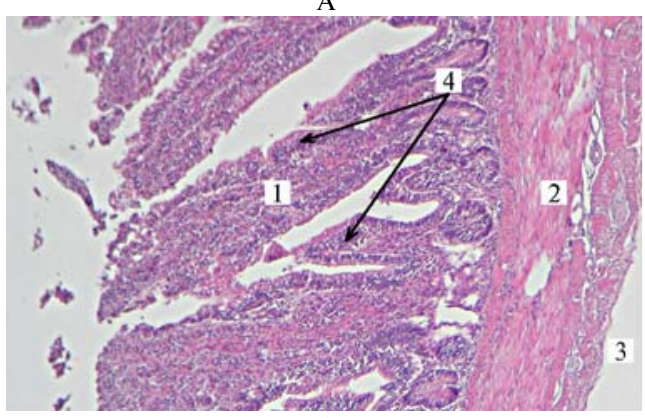

$\mathrm{C}$

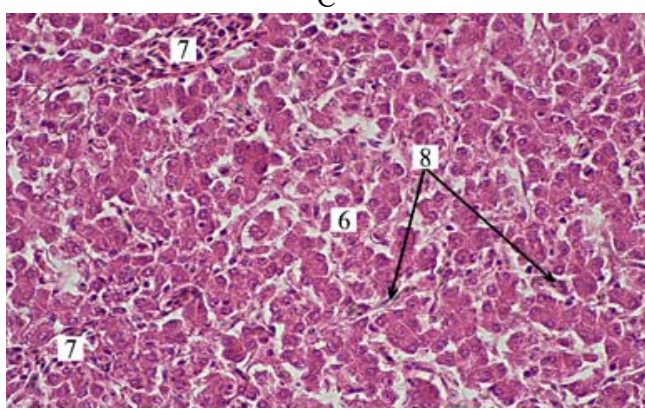

B

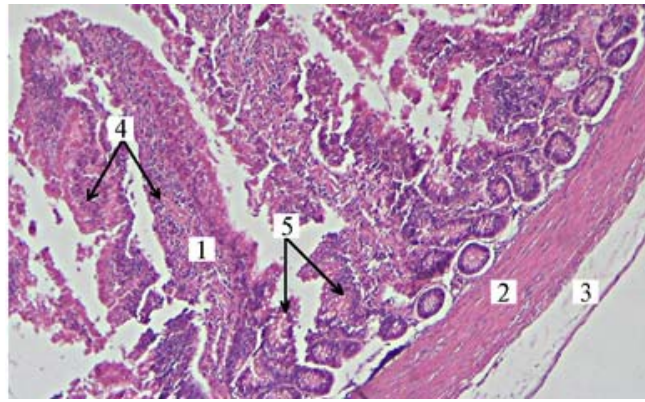

Fig. 1. Micromorphology of jejunum (A), and rectum walls $(B)$, and liver (C) in 35-days-old Cobb-500 broilers fed the diet with no feed additives or antibiotics: 1 - mucosa, $2-$ muscular membrane, 3 - serous membrane, 4 epithelial cells of the villi, $5-$ goblet cells, $6-$ hepatocytes, 7 - central vein, 8 - blood capillaries. Hematoxylin and eosin staining; magnification: $\times 100(\mathrm{~A}, \mathrm{~B})$ and $\times 400(\mathrm{C})$, light microscopy (Nikon, Japan).
B

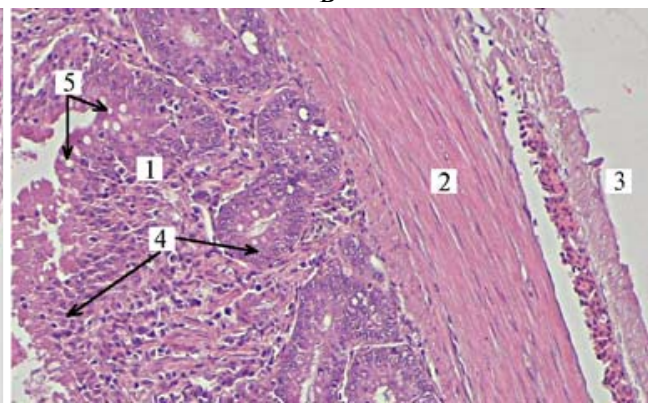

Fig. 2. Micromorphology of jejunum (A), and rectum walls (B), and liver (C) in 35-days-old Cobb-500 broilers fed the diet supplemented with AGP (Stafac 110, $180 \mathrm{~g} / \mathrm{t}$ of feed): 1 - mucosa, 2 - muscular membrane, 3 - serous membrane, $4-$ epithelial cells of the villi, $5-$ goblet cells, 6 - hepatocytes, $7-$ central vein, $8-$ blood capillaries. Hematoxylin and eosin staining; magnification: $\times 100(\mathrm{~A}), \times 200(\mathrm{~B})$, and $\times 400$ (C), light microscopy (Nikon, Japan).

Our results are consistent with the data on activating the functions of hepatocytes and immune cells of the liver stroma, and on improving the state of glandular stomach tissue in turkeys with the use of the diet supplemented with feed additive Vinivet [21]. 
4. Comparative characteristics of intestine morphometric parameters in 35-day-old Cobb-500 broiler chickens with the use of AGP Stafac 110 and apicultural product based feed additive Vinivet ( $M \pm m$, FSUE Zagorskoe EPH VNITIP vivarium, Moscow region)

\begin{tabular}{l|c|c|c|c}
\hline \multirow{2}{*}{ Group } & \multicolumn{2}{|c|}{ Large intestine (membranes), m } & \multicolumn{2}{c}{ Small intestine (membranes), m } \\
\cline { 2 - 5 } & mucosa & $\begin{array}{l}\text { muscular } \\
\text { membrane }\end{array}$ & mucosa & $\begin{array}{l}\text { muscular } \\
\text { membrane }\end{array}$ \\
\hline 1 (control, basic diet - BD) & $646,00 \pm 3,23$ & $68,40 \pm 1,43$ & $732,00 \pm 5,14$ & $101,00 \pm 6,02$ \\
2 (BD + Stafac 110, 180 g/t) & $632,00 \pm 2,11$ & $72,20 \pm 1,54$ & $697,00 \pm 3,54$ & $138,00 \pm 6,78$ \\
3 (BD + Vinivet, 5 kg/t) & $695,00 \pm 3,54$ & $89,00 \pm 2,14$ & $837,00 \pm 3,54$ & $141,00 \pm 6,02$ \\
N o t e. Basic diet was supplemented with Stafac 110 (Phibro Animal Health Corp., USA) and Vinivet (Rusoboro- \\
texport LLC, Kazan, Russia) at the doses of $180 \mathrm{~g} / \mathrm{t}$ and 5 kg/t, respectively.
\end{tabular}

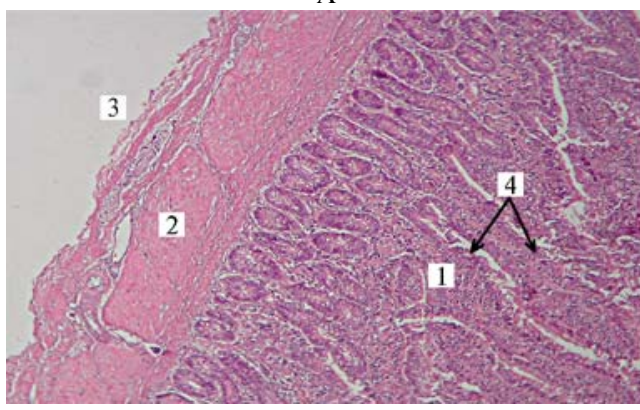

C

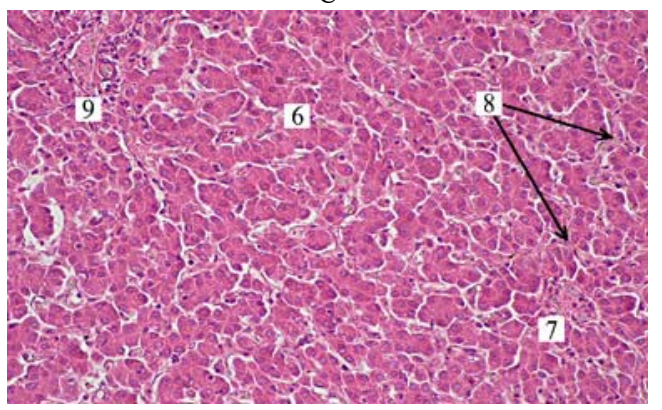

B

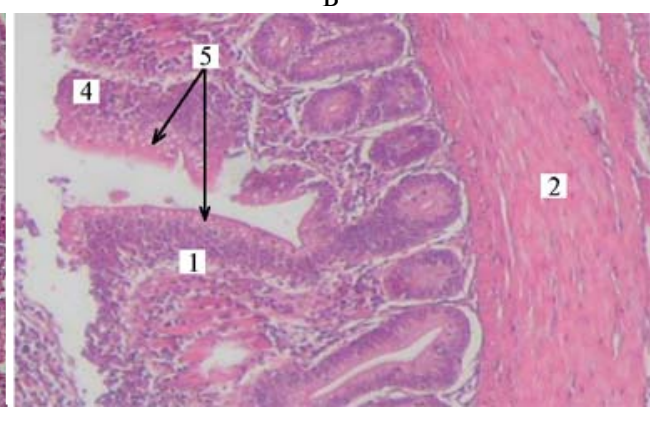

Fig. 3. Micromorphology of jejunum (A), and rectum walls (B), and liver (C) in 35-days-old Cobb-500 broilers fed the diet supplemented with apicultural product based feed additive Vinivet: 1 - mucosa, $2-$ muscular membrane, 3 - serous membrane, 4 - epithelial cells of the villi, 5 - goblet cells, $6-$ hepatocytes, $7-$ central vein, 8 - blood capillaries, 9 - liver triad. Hematoxylin and eosin staining; magnification: $\times 100(\mathrm{~A}, \mathrm{~B})$ and $\times 400(\mathrm{C})$, light microscopy (Nikon, Japan).

Thus, histological studies and GIT microflora analysis in broilers are consistent with zootechnical parameters and indicate that apicultural product based feed additive Vinivet has growth stimulating effects due to providing a complex of biologically active substances. It influences beneficially on the gastrointestinal tract, increases absorptive surface area of the small intestine mucosa due to elongation of the villi and deepening of wrinkling and crypts, and thickening of the large intestine muscle mebrane. Moreover, the product possess antiseptic properties, therefore it can be used to substitute antibiotic growth promoters in broilers.

\section{REFEREN C ES}

1. Egorov I.A., Po n o marev D.A., F is in in V.I. Korma, biologicheski aktivnye veshchestva, bezopasnost': prakticheskoe posobie [Feeds, bioactive substances, and safety - a guideline (in Russ.)]. Minsk, 2013.

2. Pozdny k kovski i V.M. Ekspertiza myasa i myasoproduktov. Kachestvo i bezopasnost' безопасность [Control of meat and meat products. Quality and safety (in Russ.)]. Novosibirsk, 2010.

3. Gorlov I.F., Mosolova N.I., Zlobina E.Yu. Vestnik RASKHN, 2013, 1: 54-56 (in Russ.).

4. Ak h me tova N.K. Materialy Mezhdunarodnoi nauchno-prakticheskoi konferentsii «Tekhnologiya i produkty zdorovogo pitaniya» [Proc. Int. Conf. «health food products and technologies» (in Russ.)]. Saratov, 2007: 4-6.

5. Rogov I.A., Dunchenko N.I., Pozdnyakovski i V.M. Bezopasnost' prodovol'stvennogo syr'ya $i$ pishchevykh produktov [Safety of food raw materials and food products (in 
Russ.)]. Novosibirsk, 2007.

6. Joint FAO/OIE/WHO Expert Workshop on Non-Human Antimicrobial Usage and Antimicrobial Resistance: scientific assessment (Geneva, 1-5 December 2003). Geneva, World Health Organisation, 2004 (http://www.who/int/foodsafety/publications/micro/en/amr.pdf, accessed 20 January 2011).

7. L a $x \mathrm{~m}$ i $\mathrm{n}$ a $\mathrm{r}$ a y $\mathrm{n}$ R., D u s e A., W a t $\mathrm{t}$ a 1 C., $\mathrm{Z}$ a i d i A.K.M., Wertheim H.F.L., Sumpradit N., Vlieghe E., Hara G.L., Gould I.M., Goossens H., Greko C., So A.D., Bigdeli M., Tomson G., Woodhouse W., Ombaka E., Peralta A.Q., Qamar F.N., Mir F., Kariuki S., Bhutta Z.A., Coates A., Bergstrom R., Wright G.D., B row n E.D., C a rs O. Antibiotic resistance - the need for global solutions. The Lancet Infectious Diseases, 2013, 13(12): 1057-1098 (doi: 10.1016/S14733099(13)70318-9).

8. Artem'eva O.A., Pereselkova D.A., Fomichev Yu.P. Dihydroquercetin, the bioactive substance, to be used against pathogenic microorganisms as an alternative to antibiotics. Agricultural Biology, 2015, 50(4): 513-519 (doi: 10.15389/agrobiology.2015.4.513eng).

9. Timoshko M.A. Mikroflora pishchevaritel'nogo trakta sel'skokhozyaistvennykh zhivotnykh [Microflora of farm animal digestive tract (in Russ.)]. Kishinev, 1990.

10. van der Wielen P.W.J.J., Keuzenkamp D.A., Lipman L.J.A., van Knapen F., Biesterveld S. Spatial and temporal variation of the intestinal bacterial community in commercially raised broiler chickens during growth. Microbiol. Ecol., 2002, 44: 286-293 (doi: 10.1007/s10482-008-9260-0).

11. Maiorka A., Dahlke F., de Azevedo Morgulis M.S.F. Broiler adaptation to posthatching period. Ciência Rural., 2006, 36: 701-708.

12. Me ad G.C. Microbes of the avian cecum: types present and substrates utilized. J. Exp. Zool., 1989, 3(Suppl.): 48-54 (doi: 10.1002/jez.1402520508).

13. Amit-Romach E., Sklan D., Uni Z. Microflora ecology of the chicken intestine using 16S ribosomal DNA primers. Poultry Sci., 2004, 83(7): 1093-1098 (doi: 10.1093/ps/83.7.1093).

14. Dibner J.J., Richards J.D., Knight C.D. Microbial imprinting in gut development and health. J. Appl. Poult. Res., 2008, 17: 174-188 (doi: 10.3382/japr.2007-00100).

15. Kizerwetter-Świd M., Binek M. Bacterial microflora of the chicken embryos and newly hatched chicken. J. Anim. Feed Sci., 2008, 17: 224-232.

16. B abaca Z. Isolation of bacterial pathogens from dead-in-shell chicken embryos from local hatcheries. J. Vet. Sci. Technol., 2014, 5(2): 170-171.

17. Rossi D.A., Fonseca B.B., de Melo R.T., da Silva Felipe G., da Silva P.L., Mendonça E.P., Filgue iras A.L.L., Beletti M.E. Transmission of Campylobacter coli in chicken embryos. Braz. J. Microbiol., 2012, 43(2): 535-543 (doi: 10.1590/S1517-83822012000200014).

18. Fuliang H.U., Hepburn H.R., Xuan H., Chen M., Daya S., Radloff S.E. Effects of propolis on blood glucose, blood lipid and free radicals in rats with diabetes mellitus. Pharmacol. Res., 2005, 51(2): 147-152 (doi: 10.1016/j.phrs.2004.06.011).

19. Golde r W. Propolis. The bee glue as presented by Graeco-Roman literature. Wurzbg Medizinhist Mitt., 2004, 23: 133-145.

20. Food and nutritional supplements /J.K. Ramsley, J.K. Donnely, N.W. Read (eds.). Springer Verlag, Berlin-Heidelberg, 2001: 12.

21. Akhmetova L.T., Garmonov S.Yu., Sibgatullin Zh.Zh., Akhmetova R.T., Sopin V.F., Zevakov I.V. Vestnik KGTU, 2011, 14(5): 154-160 (in Russ.).

22. F i s i n i n V.I., Eg o rov I.A., L e n k o va T.N., O k o l e lova T.M., I g n a t o va G.V., Panin I.G. Metodicheskie ukazaniya po optimizatsii retseptov kombikormov dlya sel'skokhozyaistvennoi ptitsy /Pod redaktsiei V.I. Fisinina [Methods of mixed feed optimization in poultry - a guideline. V.I. Fisinin (ed.) (in Russ.)]. Moscow, 2014.

23. Egorov I.A., Manukyan V.A., Okolelova T.M. et al. Metodicheskoe rukovodstvo po kormleniyu sel'skokhozyaistvennoi ptitsy /Pod redaktsiei V.I. Fisinina [Poultry feeding - a guideline. V.I. Fisinin (ed.) (in Russ.)]. Sergiev Posad, 2015.

24. Laptev G.Yu., Novikova N.I., Il'ina L.A., Iyldyrym E.A., Filippova V.A., Gorfunkel' E.P., Nikonov I.N., Fisinin V.I., Egorov I.A., Le nkova T.N., Manukyan V.A., Egorova T.V., Grozina A.A., Tishenkov D.I. Molekulyarnogeneticheskie metody opredeleniya mikroflory kishechnika i ustanovlenie normy ee soderzhaniya $v$ zheludochno-kishechnom trakte tsyplyat-broilerov [Molecular analysis of gastrointestinal tract microbiota in broiler chicks (in Russ.)]. Sergiev Posad, 2015.

25. La kin G.F. Biometriya [Biometry (in Russ.)]. Moscow, 1990.

26. Fis in in V.I., Egorov I.A., Okole lova T.M., I mangulov Sh.A. Kormlenie sel'skokhozyaistvennoi ptitsy [Poultry feeding (in Russ.)]. Sergiev Posad, 2004. 